\title{
Establishment of Geochemical Thresholds for Vanadium Throughout Korea and at Potential Development Sites Using Geochemical Map Data
}

Joo Sung Ahn ( $\sim$ jsahn@kigam.re.kr)

Korea Institute of Geoscience and Mineral Resources https://orcid.org/0000-0002-0394-9217

\section{Seung-Jun Youm}

Korea Institute of Geoscience and Mineral Resources

\section{Yong-Chan Cho}

Korea Institute of Geoscience and Mineral Resources

\section{Gil-Jae Yim}

Korea Institute of Geoscience and Mineral Resources

\section{Sang-Woo Ji}

Korea Institute of Geoscience and Mineral Resources

\section{Research Article}

Keywords: Geochemical threshold, Vanadium, Environmental management, Mineral deposit development

Posted Date: June 28th, 2021

DOl: https://doi.org/10.21203/rs.3.rs-560556/v1

License: (c) (i) This work is licensed under a Creative Commons Attribution 4.0 International License.

Read Full License

Version of Record: A version of this preprint was published at Environmental Geochemistry and Health on January 10th, 2022. See the published version at https://doi.org/10.1007/s10653-021-01159-8. 


\section{Abstract}

Geochemical maps can be used for a variety of purposes, one of which is to establish regional or local geochemical thresholds for the analyzed elements. In the case of vanadium, as industrial demand and use increases, it is necessary to expand the development of vanadium in Korea. However, the environmental management standards are insufficient. Therefore, in this study, using geochemical data, we derived geochemical threshold values for the entire country and areas with potential for the development of vanadium deposits. The regional (country-wide) threshold value was derived using logarithmic transformation of raw data $(\mathrm{N}=23,548)$ of the first- and second-order stream sediments collected across the country in the late 1990s and the early $2000 \mathrm{~s}$. The median +2 median absolute deviation (MAD) and Tukey inner fence (TIF) values were $116 \mathrm{mg} / \mathrm{kg}$ and $200 \mathrm{mg} / \mathrm{kg}$, respectively. Of these, the TIF standard, which showed $0.6 \%$ of data exceeding the threshold, was judged to be appropriate for distinguishing clear enrichment or contamination of vanadium. In the case of the Geumsan and Pocheon, areas with potential for vanadium development, the TIF and median + 2 MAD values of $259 \mathrm{mg} / \mathrm{kg}$ and $218 \mathrm{mg} / \mathrm{kg}$, respectively, can be used as the criteria for evaluating the impact of environmental pollution before and after deposit development. Likewise, by deriving threshold values of the target elements using geochemical map data, it is possible to provide basic environmental information for geochemical evaluation and follow-up management in advance during large-scale site development.

\section{Introduction}

Vanadium is widely used not only in alloys but also for specialized industrial applications. Recently, a vanadium redox flow battery has emerged as a next-generation large-capacity energy storage device that will replace the existing lithium-ion battery, and the demand for vanadium is expected to increase further (Kim and Jeon 2019; Ko et al. 2021). However, most of the world's reserves are stored in three countries, China, Russia, and South Africa, and more than $90 \%$ of the world's production is concentrated in these countries. In Korea, the possibility of the existence of vanadium deposits is suggested in the Geumsan area located in the central part and the Pocheon area located in the northern part of the country (Lee et al. 1997; Kim et al. 1994), and high-efficiency beneficiation and eco-friendly smelting technologies are being developed to secure stable vanadium raw materials (Jeon et al. 2021).

Vanadium, like most heavy metal elements, has no human health effect or may be beneficial at low concentrations; however, it can be toxic at high concentrations. Prolonged exposure to vanadium has been shown to have toxic effects on the respiratory and digestive systems, kidneys, liver, skin, immune system, and cardiovascular system (Baken et al. 2012; Jayawardana et al. 2015). In addition, vanadium compounds are reported to be medically carcinogenic (Korbeci et al. 2012) and are classified as potentially carcinogenic substances (Group 2B) by the International Agency for Research on Cancer (IARC 2021). However, compared to known toxic heavy metal elements such as lead and cadmium, environmental studies on vanadium are insufficient, and environmental regulations concerning soils and drinking water are also insufficient worldwide. There are few countries in which standards and 
regulations for environmental pollution with vanadium are accepted. For example, in Canada, $130 \mathrm{mg} / \mathrm{kg}$ is the optimum range in soil for vascular plants (CCME, 1999), and The Netherlands (42 mg/kg), Czech Republic $(180 \mathrm{mg} / \mathrm{kg})$, and Slovenia $(120 \mathrm{mg} / \mathrm{kg})$ developed similar guidelines for soil invertebrates and plants (Imtiaz et al. 2015). In Korea, as in most other countries, the enforced regulation of vanadium has not been established for soil, water, and the atmosphere. As a preparatory stage for setting standards, basic studies have been conducted on the distribution of vanadium concentrations and behavior characteristics in industrial areas, abandoned mines, roads, and general soils (Lee et al. 2018).

Geochemical maps show the dispersion patterns of geochemical elements based on samples of the Earth's surface, such as sediment, soil, glacial till, and floodplain, and such maps are prepared not only for the purpose of exploration of mineral resources, but also for environmental monitoring, support for land use, agricultural production, and medical geology. In Korea, geochemical mapping started in the 1980s based on old 1:50,000 scale geographic maps in units of $415 \mathrm{~km}^{2} /$ sheet for mineral resource exploration in the Taebaeksan mineralization zone and its neighboring areas. In the early stages, heavy mineral samples that were more effective in mineral resource exploration were targeted. Since then, the geochemical survey has been conducted mainly with sediment samples that can be used even in the field of environmental geochemistry, and the survey area has been expanded to units of $624 \mathrm{~km}^{2} /$ sheet using new 1:50,000 scale topographic maps. Since the late 1990s, regional surveys have been conducted across the country, and province-based geochemical maps have been prepared for the purpose of deriving natural background values for each hazardous element and setting evaluation criteria; finally, a national geochemical atlas was published with the compiled dataset (KIGAM 2000, 2003, 2007).

One of the various purposes of creating a geochemical map is to derive the geochemical background and threshold values. The geochemical background concentration of a specific element can be said to indicate the average concentration exhibited by geological conditions and geochemical reactions in a natural environment where no contamination has occurred. Geochemical surveys, excluding anthropogenic sources of pollution as much as possible in a certain area, are conducted, and the background values can be obtained through statistical processing of the analytical dataset. The data are presented as quartiles, means, medians, and minimum and maximum values. The geochemical threshold can be defined as the upper limit of these background values (Reimann and Garrett 2005; Reimann et al. 2005). In terms of environmental management, the geochemical threshold values can be used as criteria for the determination of pollution or target concentrations for remediation, and are sometimes referred to as reference values, preventive values, target values, or maximum allowable values (Inácio et al. 2008). Crustal content or preindustrial content from the literature may be used as criteria; however, as these do not reflect natural regional changes, the geochemical background or threshold data of soils or sediments were derived and used in the survey areas (Zhou et al. 2019; Baize and Sterckeman 2001; Galán et al. 2008; Tian et al. 2017). In the case of vanadium, domestically and internationally, environmental standards are insufficient; therefore, the use of regional or local geochemical threshold data is necessary. In particular, this information can be used as a pollution criterion or remediation target value in post-mine development impact assessment and can be applied as basic data for risk assessment. 
In this study, the national-scale regional threshold values of Korea and the local threshold values of potential mine development areas are suggested for the environmental management of areas where ore development is planned or is likely owing to the increasing demand for vanadium mineral resources.

\section{Method}

\section{Geochemical threshold}

The geochemical threshold is set as a criterion for classifying the background and outliers of the dataset to distinguish the natural distribution content and anthropogenic pollution patterns of potential toxic elements in environmental geochemistry, or to distinguish between mineralized and barren zones in exploration geochemistry. For points above the threshold, further investigation is required depending on the research purpose, whether it is a pollution source investigation for environmental management or a detailed drilling investigation for mineral exploration (Reimann and Caritat 2017).

Various methods are utilized to derive the geochemical threshold value, and the following statistics are mainly used.

- Mean +2 standard deviation (SD)

- Median +2 median absolute deviation (MAD)

- Tukey inner fence $(\mathrm{TIF})=\mathrm{Q} 75+1.5$ inter-quartile range (IQR)

- Analysis of cumulative probability (CP) plot

- Q90, Q95, Q97.5, and Q98

In this study, the relatively simple and effective median +2 MAD value was adopted. This has the advantage of being less affected by the outliers of the geochemical dataset than the mean +2 SD method developed in exploration geochemistry; however, very conservative (low) threshold values are delivered, that is, it results in the suggestion of many sites that need further investigation (Reimann et al. 2018). In this study, because general geochemical data tend to be right-skewed, a log-transformation was performed to create a symmetric data distribution, and the statistic was calculated using the formula below. The value was inversely transformed to obtain the threshold value.

threshold $=10^{\mathrm{b}}$

where $b=\left(\operatorname{median}_{i}\left(\log x_{i}\right)+2 M A D_{j}\left(\log x_{j}\right)\right)$

$$
\operatorname{MAD}_{\mathrm{i}}\left(\mathrm{x}_{\mathrm{i}}\right)=\operatorname{median}_{\mathrm{i}}\left|\mathrm{x}_{\mathrm{i}}-\operatorname{median}_{\mathrm{j}}\left(\mathrm{x}_{\mathrm{j}}\right)\right|
$$

In addition, the commonly used TIF was calculated. This method was also applied to the log-transformed data and was derived using the following formula, using a box plot. 
$\mathrm{TIF}=\mathrm{Q} 75+1.5 \mathrm{IQR}$

where IQR $=$ Q75 - Q25 $\left(75^{\text {th }}-25^{\text {th }}\right.$ percentile $)$.

In this method, the TIF value is determined based on a box plot and depends purely on the distribution pattern of the geochemical analysis data, and the threshold for outliers can be defined even if they do not exist in the data (i.e., TIF > maximum).

The calculation of the geochemical threshold using the above method has been applied to 59 elements of surface soil in the course of the Australian National Geochemical Survey Project (Reimann and Caritat 2017), and was also applied in the Geochemical Mapping of Agricultural Soil project to prepare geochemical maps for 53 elements of the soil of the European continental arable land (Reimann et al. 2018). Recent examples include the establishment of geochemical thresholds in Bulgarian soil quality monitoring networks (Yotova et al. 2018), geochemical assessment of technology-critical elements in Slovenia (Lucic et al. 2020), geochemical anomalies of critical elements in western Andalusia, Spain (Fernandez-Caliania et al. 2020), and geochemical mapping in the Carajas mineral province, Brazil (Salomao et al. 2020).

In addition, a comparative analysis was conducted with the $90^{\text {th }}, 95^{\text {th }}$, and $97.5^{\text {th }}$ percentiles of the original data, which correspond to the upper outlier criteria of $10 \%, 5 \%$, and $2.5 \%$, respectively. The cumulative probability distribution plots can be used as an alternative method for defining the threshold value by analyzing the inflection points of the curve; however, this is rather subjective (Reimann et al. 2005) and has been omitted from the current study because of the lack of data points for the local areas. All statistical analyses and threshold calculations were performed using the IBM SPSS software (version 19.0).

\section{Regional geochemical map}

The national geochemical mapping project was performed with the final goal of producing a geochemical map for each element and establishing domestic evaluation criteria for the evaluation of geochemical disasters in Korea (KIGAM 2000, 2003, 2007). This effort was divided across the western and eastern halves of the country and was promoted as a two-stage project of three years each from November 1996. The geochemical map was produced in compliance with the IUGS Global Geochemical Baselines mapping program (Darnley et al. 1995). As a result, sample collection was performed with surficial sediments ( $<150 \mu \mathrm{m}$ grain size fraction) in the first- or second-order streams as representative samples of national catchment basins. The entire target area was approximately $97,753 \mathrm{~km}^{2}$, and 23,696 samples were collected at a density of approximately one site per $4.13 \mathrm{~km}^{2}$. In addition, various site information was recorded, such as site geology, mine locations, upper land uses, levee characteristics, possible pollution sources, and stream water characteristics ( $\mathrm{pH}$ and electrical conductivity).

For stream sediment samples, quantitative analysis was performed on 10 species of the main constituents, including $\mathrm{Al}_{2} \mathrm{O}_{3}, \mathrm{CaO}, \mathrm{Fe}_{2} \mathrm{O}_{3}, \mathrm{~K} 2 \mathrm{O}, \mathrm{MgO}, \mathrm{MnO}, \mathrm{Na}_{2} \mathrm{O}, \mathrm{P}_{2} \mathrm{O}_{5}, \mathrm{SiO}_{2}$, and $\mathrm{TiO}_{2}$, and 26 species of 
trace elements such as As, Ba, Be, Bi, Cd, Ce, Co, Cr, Cs, Cu, Eu, Hf, Li, Mo, Nb, Ni, Pb, Rb, Sb, Sc, Sr, Th, V, $\mathrm{Yb}, \mathrm{Zn}$, and $\mathrm{Zr}$ using $\mathrm{X}$-ray fluorescence, inductively coupled plasma-atomic emission spectroscopy, and neutron activation analysis. Chemical decomposition for the analysis of trace components was conducted using nitric acid, perchloric acid, hydrofluoric acid, and hydrochloric acid. Certified standard samples of stream sediments were applied to every 100 sample analyses for quality control.

A specific computational software (KGCM1) was developed for optimal geochemical map processing, taking into account the domestic water system and investigation conditions. Finally, provincial geochemical maps for 22 elements and water quality ( $\mathrm{pH}$ and $\mathrm{EC}$ ) were produced using an interpolation technique of inverse distance weighting. Three-component geochemical maps (RGB photometric method) for components with high concomitant relationships were also prepared. Subsequently, national survey data for 20 components (18 elements and water $\mathrm{pH}$ and EC) were compiled and published in the form of a geochemical atlas. In addition, natural background values for each of the 36 elements of all geological

units (complex/rock/supergroup/group/strata) were set as the geochemical evaluation criteria, which are essential for quantitative and qualitative evaluation of geochemical disasters (KIGAM 2007).

In this study, 23,548 chemical analytical data were retrieved to calculate the regional geochemical threshold of vanadium in Korea. In the Geumsan and Pocheon, which were selected as potential vanadium production sites, areas that could be affected by mine development were established as research sites, and a sufficient number of samples were secured considering the geology and topography. To derive the local geochemical threshold for each area, data on 18 elements from 33 locations in Geumsan and 20 locations in Pocheon were collected.

\section{Results And Discussion}

\section{Regional distribution of vanadium}

A vanadium geochemical map of Korea is shown in Figure 1. Points in blue indicate a low content of less than $50 \mathrm{mg} / \mathrm{kg}$, and those in red indicate a high content of $100 \mathrm{mg} / \mathrm{kg}$ or more. In the manual of the Geochemical Atlas of Korea (KIGAM 2007), the median value of vanadium by major geological units is presented as the geochemical background value (Appendix 1). It appears at a relatively high concentration of $80 \mathrm{mg} / \mathrm{kg}$ or more in the Okcheon Supergroup, Josen Supergroup, Gyeonggi Gneiss Complex, and Precambrian banded biotite gneiss. In contrast, it is relatively low (less than $50 \mathrm{mg} / \mathrm{kg}$ ) in plutonic rocks including granites of the Cretaceous, Jurassic, and Permo-Triassic periods. The distribution of vanadium content in the geochemical map agrees well with the distribution of such rock formations (KIGAM 2007). In many cases, the change in the geochemical content of the surface sample is controlled by underground or catchment lithology. Particularly, in the case of vanadium in Korea, there is no anthropogenic pollution effect, such as mine development, and the levels depend solely on natural geochemical variations. In the geochemical map, specific enriched zones in the range of $100-300 \mathrm{mg} / \mathrm{kg}$ are proposed and can be selected as promising sites for vanadium deposit development through 
additional detailed geochemical and geophysical investigations. Such mineral deposit development also requires environmental and social aspects to be taken into consideration.

\section{Regional geochemical threshold of vanadium}

The vanadium content of the retrieved stream sediment samples in Korea was in the range of 2.1-1,000 $\mathrm{mg} / \mathrm{kg}$, with a median value of $66.8 \mathrm{mg} / \mathrm{kg}$ and an average value of $71.5 \mathrm{mg} / \mathrm{kg}$ (Fig. 2). As can be seen in the histograms and box plots, the original data (Fig. 2(a)) of vanadium content are largely skewed to the right (skewness 4.34) with 821 outliers exceeding the upper inner fence value of $142 \mathrm{mg} / \mathrm{kg}$, which is a typical asymmetric pattern of geochemical data. Therefore, a common logarithm transformation was applied for calculation of the geochemical threshold resulting in a generally symmetrical form as shown in Figure 2(b). The descriptive statistics and calculated geochemical threshold values for vanadium in stream sediments in Korea are listed in Table 1. The calculated median +2 MAD was $116 \mathrm{mg} / \mathrm{kg}$, with 1,908 data exceeding the threshold value, accounting for $8.1 \%$ of the total data. This value was higher than the $90^{\text {th }}$ percentile $(110 \mathrm{mg} / \mathrm{kg})$ and lower than the $95^{\text {th }}$ percentile $(131 \mathrm{mg} / \mathrm{kg})$. In the case of TIF, the threshold value was $200 \mathrm{mg} / \mathrm{kg}$, with 151 data points (corresponding to $0.6 \%$ ) exceeding this value. The threshold value was much higher than even the $97.5^{\text {th }}$ percentile $(151 \mathrm{mg} / \mathrm{kg})$.

The average upper crust content that can be considered as the geochemical background concentration of vanadium is suggested to be $53 \mathrm{mg} / \mathrm{kg}$ (Wedepohl 1995), $97 \mathrm{mg} / \mathrm{kg}$ (McDonough and Sun 1995), 110 $\mathrm{mg} / \mathrm{kg}$ (Adriano 1986), and $135 \mathrm{mg} / \mathrm{kg}$ (Kabata-Pendias 2011) (Table 1). The average soil content is suggested to be $90 \mathrm{mg} / \mathrm{kg}$ (Bowen 1979), $108 \mathrm{mg} / \mathrm{kg}$ (Alloway 1995), and $129 \mathrm{mg} / \mathrm{kg}$ (Kabata-Pendias 2011), and in Korean domestic natural soil the reference suggested is $50 \mathrm{mg} / \mathrm{kg}$ (Lee et al. 2018). Compared with these values, the median +2 MAD value of $116 \mathrm{mg} / \mathrm{kg}$ as a geochemical threshold has no discrimination and is a conservatively low standard leading to too many points to be evaluated as a vanadium enrichment or contamination situation. In the case of TIF, the obtained value is two to four times that of these threshold values, and only $0.6 \%$ of the total data exceeded the threshold limit. This is much lower than the $2.5 \%$ outlier ratio of classical statistics, and can be judged as a completely enriched or contaminated point based on a rather high trend. Recommended guidelines for vanadium are 130 $\mathrm{mg} / \mathrm{kg}$ in Canada, $42 \mathrm{mg} / \mathrm{kg}$ in The Netherlands, $180 \mathrm{mg} / \mathrm{kg}$ in the Czech Republic, and $120 \mathrm{mg} / \mathrm{kg}$ in Slovenia (Imtiaz et al. 2015). Compared with these values, the geochemical threshold in this study was set to be somewhat higher in Korea. To establish an effective environmental standard, it is necessary to comprehensively consider the human exposure pathway and risk assessment, and the geochemical threshold derived here is judged to be adequate for use as basic data for this process.

\section{Local distribution and geochemical threshold of vanadium}

The distribution of the Okcheon Supergroup in the Geumsan area and the iron mine in the Pocheon area are promising areas for the development of vanadium deposits in Korea. The presence of high vanadium content was known in accordance with the high uranium content in the Geumsan area from previous exploration surveys. A mining company has submitted an excavation proposal for vanadium production 
with these data, although there has been no further progress till date owing to opposition from residents. The iron mine in the Pocheon area, in which titanium-bearing magnetite is developed in an alkaline porphyry rock body, also has ores of vanadium titano-magnetite.

The main geology of the Geumsan area comprises the Okcheon Supergroup (Og1, Og2, and Og3 in Fig. 3), the Cretaceous acidic dyke, and the Jurassic granite (Fig. 3). Vanadium is expected to be adsorbed by carbonaceous substances in metamorphic sedimentary rocks such as black slate, green phyllite, limestone, and coal seams of the Okcheon Supergroup. Vanadium can also be present as a substitute in the structure of muscovite minerals. Lee et al. (1997) found green barium-vanadium muscovite (vanadium-oellachrite) in the coaly metapelite of the same Supergroup in a nearby area. The vanadium content of the coaly metapelite ranged from 123 to $8,112 \mathrm{mg} / \mathrm{kg}(\mathrm{N}=42)$, and the bariumvanadium muscovite was suggested as the ultimate source of vanadium. Lower phyllite formation (Og2 in Fig. 3) has low-grade coal seams, and a similar source of vanadium is expected in the study area. The Pocheon area comprises Precambrian metasedimentary rocks that are infiltrated with porphyry, biotite granite, quartz porphyry, and basic dykes (Fig. 4). The titaniferous magnetite exists as a bulk, skarn-type, and layered ore body, and the production of vanadium resources is expected to be promising for the development of magnetite ore.

Table 2 shows the results of the geochemical threshold calculation using median +2 MAD and TIF based on log-transformed data for 33 locations in Geumsan and 20 locations in Pocheon around each potential development site (Figs. 3 and 4). For the other analyzed elements, the statistics and calculated threshold values in each area are listed in Appendices 2 and 3, respectively. The vanadium content in the Geumsan area ranged from 56 to $270 \mathrm{mg} / \mathrm{kg}$, with an average of $122 \mathrm{mg} / \mathrm{kg}$ and median of $116 \mathrm{mg} / \mathrm{kg}$. Regarding geochemical thresholds, the median +2 MAD was $177 \mathrm{mg} / \mathrm{kg}$ and the TIF was $259 \mathrm{mg} / \mathrm{kg}$. This is a much higher result than the value derived for the entire country, indicating that vanadium is relatively enriched in this area. In the overall dispersion pattern, there were four points that were higher than the median +2 MAD threshold, and four points that were higher than the median +1 MAD, and the amounts were generally high in the Okcheon Supergroup distribution area (Fig. 5). The arsenic content in groundwater from the Okcheon Supergroup metamorphic sedimentary rocks in the Geumsan area has been surveyed and found to be concentrated by typical geogenic sources (Ahn 2012; Ahn and Cho 2013). The oxidation reaction of sulfide minerals in metasedimentary rocks and locally mineralized zones seems to be ultimately responsible for the existence of arsenic in the groundwater. The enrichment of vanadium owing to the geological origins of the Okcheon Supergroup also needs to be investigated more extensively.

The vanadium content in the Pocheon area ranged from 37 to $236 \mathrm{mg} / \mathrm{kg}$, with an average of $100 \mathrm{mg} / \mathrm{kg}$ and median of $93 \mathrm{mg} / \mathrm{kg}$. The median +2 MAD and TIF geochemical thresholds were $218 \mathrm{mg} / \mathrm{kg}$ and 377 $\mathrm{mg} / \mathrm{kg}$, respectively (Table 2). The derived threshold values were higher than those of the Geumsan area. This is because the difference between the $75^{\text {th }}$ and $25^{\text {th }}$ percentiles is greater, that is, the content dispersion is larger. Regarding spatial distribution within the area, one point was higher than the median +2 MAD and three points were higher than the median +1 MAD around the iron mine; this result is 
associated with the distribution of vanadium titano-magnetite ore bodies (Fig. 6). When compared to the $200 \mathrm{mg} / \mathrm{kg}$ level determined as the domestic regional geochemical threshold, we believe that the value of $259 \mathrm{mg} / \mathrm{kg}$ obtained using the TIF method for the Geumsan area, and the value of $218 \mathrm{mg} / \mathrm{kg}$ obtained using the median +2 MAD for the Pocheon area are appropriate and valid as the local geochemical threshold for each research area.

Based on the correlation between the 18 elements analyzed together with vanadium (Table 3), vanadium was seen to have a high correlation coefficient of 0.7 or more with barium in the Geumsan area, in particular. As mentioned above, the occurrence of barium-vanadium muscovite, in which vanadium and barium are substituted, has been reported in the Okcheon Supergroup (Lee et al. 1997), and this good correlation supports a similar source of vanadium in the area. In the Pocheon area, high correlation coefficients of 0.8 or more were obtained between vanadium and $\mathrm{Fe}, \mathrm{Ti}$, and $\mathrm{Co}$. It is well known that vanadium is more abundant in mafic rocks than in felsic rocks because it readily substitutes for Fe in minerals (Huang et al. 2015). In general, titaniferous magnetite is the principal source of mined vanadium, which is produced primarily as a byproduct of Fe and Ti mining. The good correlations of the study area are also indicative of the presence of vanadium in the form of the vanadium titano-magnetite deposits in the underlying basic rocks. Figure 7 shows the correlations between vanadium and $\mathrm{Fe}, \mathrm{Ti}$, and $\mathrm{Ba}$ in each area. Here, the Pocheon area shows a high linear correlation with $\mathrm{Fe}$ and $\mathrm{Ti}$, and the Geumsan area shows a relatively good linear correlation with $\mathrm{Ba}$. The differences in the origins of vanadium were well distinguished.

The fact that the calculated geochemical thresholds in the Geumsan and Pocheon areas are substantially higher than those of the entire country implies the enrichment of vanadium in these areas, suggesting that, in response, environmental management standards should be set high. The derived geochemical threshold can be used as basic data for assessing environmental pollution resulting from surface disturbances or waste generation because of the development of vanadium deposits in these areas. In addition, it is also possible to directly compare the change in the content of vanadium at individual sampling points after deposit development to evaluate the effect of each point. If environmental pollution caused by such development is confirmed, it can be set as a target for remediation in the future. Simultaneously the analyzed heavy metals such as $\mathrm{Cr}, \mathrm{Cu}, \mathrm{Pb}$, and $\mathrm{Zn}$ can also be used to assess the environmental impact of deposit development.

\section{Conclusion}

Regional and local geochemical thresholds for vanadium, which has insufficient environmental standards, were derived using the first- or second-order sediment geochemical data from the Korean national geochemical map prepared in the early 2000s. As regional thresholds of vanadium for the country, the median + 2 MAD and TIF values were determined as $116 \mathrm{mg} / \mathrm{kg}$ and $200 \mathrm{mg} / \mathrm{kg}$, respectively. When applying the TIF, the outlier rate was $0.6 \%$, which is a rather high standard; however, it is expected to be used as a standard to clearly classify enrichment caused either by the mineralization of vanadium or by anthropogenic contamination through vanadium mineral development in Korea. 
Regarding local geochemical thresholds for the Geumsan and Pocheon areas, which were suggested to have potential for vanadium development, the derived values were $259 \mathrm{mg} / \mathrm{kg}$ (TIF) and $218 \mathrm{mg} / \mathrm{kg}$ (median +2 MAD), respectively. We believe that each value will serve as a basis for evaluating the developmental impact in each area. The spatial distribution of the vanadium content in each area was in good agreement with the enrichment due to geological and mineralization factors. In addition, the different enrichment factors of vanadium could be distinguished when evaluating the correlation between vanadium and other analytical elements.

Thus, it is possible to provide basic environmental data for geochemical evaluation and follow-up management in advance when developing mineral resources and large-scale sites such as industrial complexes and airports.

\section{Declarations}

\section{Acknowledgements}

This research was supported by the Basic Research Project (Code: 21-3412-1) of the Korea Institute of Geoscience and Mineral Resources funded by the Ministry of Science and ICT, Korea.

\section{References}

1. Adriano DC (1986) Trace elements in the terrestrial environment. Spring-Verlag, New York

2. Ahn JS (2012) Geochemical occurrences of arsenic and fluoride in bedrock groundwater: a case study in Geumsan County, Korea. Environ Geochem Health 34:43-54. http://doi.org/10.1007/s10653-011-9411-5

3. Ahn JS, Cho YC (2013) Predicting natural arsenic contamination of bedrock groundwater for a local region in Korea and its application. Environ Earth Sci 68:2123-2132. http://doi.org/10.1007/s12665012-2179-9

4. Alloway BJ (ed) (1995) Heavy Metals in Soils. Blackie Academic \& Professional

5. Baize D, Sterckeman T (2001) Of the necessity of knowledge of the natural pedogeochemical background content in the evaluation of the contamination of soils by trace elements. Sci Total Environ 264:127-139. http://doi.org/10.1016/s0048-9697(00)00615-x

6. Baken S, Larsson MA, Gustafsson JP, Cubadda F, Smolders E (2012) Aging of vanadium in soils and consequences for bioavailability. Eur J Soil Sci 63:839-847. http://doi.org/10.1111/j.13652389.2012.01491.x

7. Bowen HJM (1979) Environmental chemistry of the elements. Academic Press, London

8. CCME (Canadian Council of Ministers of the Environment) (1999) Canadian Soil Quality Guidelines for the Protection of Environmental. Vanadium, and Human Health 
9. Darnley AG, Bj€orklund A, Bølviken B, Gustavsson N, Koval PV, Plant JA, Steenfelt A, Tauchid M, Xuejing X, Garrett RG, Hall GEM (1995) A Global Geochemical Database for Environmental and Resource Management. Final Report of IGCP Project 259. Earth Sciences 19. UNESCO Publishing, Paris

10. Fernandez-Caliani JC, Romero-Baena A, Gonzalez I, Galan E (2020) Geochemical anomalies of critical elements (Be, Co, Hf, Sb, Sc, Ta V, W, Y and REE) in soils of western Andalusia (Spain). Appl Clay Sci 191:105610. https://doi.org/10.1016/j.clay.2020.105610

11. Galán E, Fernández-Caliani JC, González I, Aparicio P, Romero A (2008) Influence of geological setting on geochemical baselines of trace elements in soils. Application to soils of South-West Spain. J Geochem Explor 98:89-106. https://doi.org/10.1016/j.gexplo.2008.01.001

12. Guagliardi I, Cicchella D, De Rosa R, Ricca N, Buttafuoco G (2018) Geochemical sources of vanadium in soils: Evidences in a southern Italy area. J Geochem Explor 184:358-364.

http://dx.doi.org/10.1016/j.gexplo.2016.11.017

13. Huang JH, Huang F, Evans L, Glasauer S (2015) Vanadium: Global (bio)geochemistry. Chem Geol 417:68-89. http://dx.doi.org/10.1016/j.chemgeo.2015.09.019

14. IARC (International Agency for Research on Cancer) (2021) IARC monographs on the identification of carcinogenic hazards to humans, Agents classified by the IARC monographs, Volumes 1-129. https://monographs.iarc.who.int/agents-classified-by-the-iarc/. Accessed 1 May 2021

15. Imtiaz M, Rizwan MS, Xiong S, Li H, Ashraf M, Shahzad SM, Shahzad M, Rizwan M, Tu S (2015) Vanadium, recent advancements and research prospects: A review. Environ Intl 80:79-88. http://dx.doi.org/10.1016/j.envint.2015.03.018

16. Inácio M, Pereira V, Pinto M (2008) The Soil Geochemical Atlas of Portugal: Overview and applications. J Geochem Explor 98:22-33. http://doi.org/10.1016/j.gexplo.2007.10.004

17. Jayawardana DT, Pitawala HMTGA, Ishiga H (2015) Geochemical evidence for the accumulation of vanadium in soils of chronic kidney disease areas in Sri Lanka. Environ Earth Sci 73:5415-5424. http://doi.org/10.1007/s12665-014-3796-2

18. Jeon HS, Baek SH, Han Y, Go BH, Jeong D, Kim S (2021) Developing technology necessary to produce domestic vanadium resources. J Korean Soc Miner Enegy Resour Eng 58:66-74. https://doi.org/10.32390/ksmer.2021.58.1.066

19. Kabata-Pendias A (2011) Trace elements in soils and plants, 4th edn. CRC Press, Boca Raton

20. KIGAM (2000) National geochemical mapping for natural environment. Korea Institute of Geoscience \& Mineral Resources, Report N2-03-01-0A-04

21. KIGAM (2003) National baseline mapping for geochemical hazard assessment. Korea Institute of Geoscience \& Mineral Resources. Report 00-J-ND-01-B-17

22. KIGAM (2007) :1,800,000), Series 9. In: Geochemical atlas of Korea, (1. Korea Institute of Geoscience \& Mineral Resources

23. Kim KH, Lee HJ, Chon HT (1994) Ore genesis of the Yonchon titaniferous iron ore deposits, South Korea. Econ Environ Geol 27:117-130. 
https://www.koreascience.or.kr/article/JAKO199423034628031.page

24. Kim SM, Jeon SM (2019) Separation processes for self-sufficient recovery of vanadium resources in Korea. J Korean Soc Miner Energy Resour Eng 56:292-302.

https://doi.org/10.32390/ksmer.2019.56.3.292

25. Ko B, Han Y, Heong D, Kim S, Lee S, Jeon HS (2021) Development of separation technique for the production of vanadium from domestic vanadium titanomagnetite ore. J Korean Soc Miner Enegy Resour Eng 58:2-9. https://doi.org/10.32390/ksmer.2021.58.1.002

26. Korbecki J, Baranowska-Bosiacka I, Gutowska I, Chlubek D (2012) Biochemical and medical importance of vanadium compounds. Acta Biochim Pol 59:195-200. http://www.actabp.pl/pdf/2_2012/195.pdf

27. Lee CH, Lee HK, Shin MA (1997) Barium-vanadium muscovite of coaly metapelite in the Hoenam area of the Ogcheon Supergroup, Korea. J Geol Soc Korea 33:55-64. http://www.dbpia.co.kr/journal/articleDetail?nodeld=NODE01601121

28. Lee HG, Noh HJ, Yoon JK, Lim JH, Lim GH, Kim HK, Kim JI (2018) Evaluation of the concentration distribution and the contamination influences for beryllium, cobalt, thallium and vanadium in soil around the contaminated sources. J Soil Groundwater Environ 23:48-59. https://doi.org/10.7857/JSGE.2018.23.4.048

29. Lučić M, Vdović N, Bačić N, Mikac N (2020) Geochemical characteristics and preliminary assessment of geochemical threshold values of technologycritical elements in soils developed on different geological substrata along the Sava river headwaters (Slovenia, Croatia). Arch Environ Contam Toxicol. https://doi.org/10.1007/s00244-020-00781-4

30. McDonough WF, Sun S (1995) The composition of the Earth. Chem Geol 120:223-253. https://doi.org/10.1016/0009-2541(94)00140-4

31. Reimann C, Caritat PDe (2017) Establishing geochemical background variation and threshold values for 59 elements in Australian surface soil. Sci Tot Environ 578:633-648. https://doi.org/10.1016/j.scitotenv.2016.11.010

32. Reimann C, Fabian K, Birke M, Filzmoser P, Demetriades A, Negrel P, Oorts K, Matschullat J, Caritat, PDe, The GEMAS Project Team (2018) GEMAS: Establishing geochemical background and threshold for 53 chemical elements in European agricultural soil. Appl Geochem 88:302-318. http://dx.doi.org/10.1016/j.apgeochem.2017.01.021

33. Reimann C, Filzmoser P, Garrett RG (2005) Background and threshold: critical comparison of methods of determination. Sci Tot Environ 336:1-16. http://doi.org/10.1016/j.scitotenv.2004.11.023

34. Reimann C, Garrett RG (2005) Geochemical background-concept and reality. Sci Tot Environ 350:1227. http://doi.org/10.1016/j.scitotenv.2005.01.047

35. Salomao GN et al (2020) Geochemical mapping in stream sediments of the Carajas Mineral Province: Background values for the Itacaiúnas River watershed, Brazil. Appl Geochem 118:104608. https://doi.org/10.1016/j.apgeochem.2020.104608 
36. Tian K, Huang B, Xing Z, Hu W (2017) Geochemical baseline establishment and ecological risk evaluation of heavy metals in greenhouse soils from Dongtai, China. Ecol Indic 72:510-520. http://dx.doi.org/10.1016/j.ecolind.2016.08.037

37. Wedepohl KH (1995) The composition of the continental crust. Geochem Cosmochim Acta 59:12171232. https://doi.org/10.1016/0016-7037(95)00038-2

38. Yotova G, Padareva M, Hristova M, Astel A, Georgieva M, Dinev N, Tsakovski S (2018) Establishment of geochemical background and threshold values for 8 potential toxic elements in the Bulgarian soil quality monitoring network. Sci Tot Enviro 643:1297-1303.

http://doi.org/10.1016/j.scitotenv.2018.06.237

39. Zhou CY, Gao L, Xu D, Gao B (2019) Geochemical baseline establishment, environmental impact and health risk assessment of vanadium in lake sediments, China. Sci Tot Environ 660:1338-1345. https://doi.org/10.1016/j.scitotenv.2019.01.093

\section{Tables}

Table 1 Statistics and geochemical threshold values for vanadium of stream sediments in Korea 


\begin{tabular}{|lll|}
\hline Statistics & $\mathrm{V}(\mathrm{mg} / \mathrm{kg})$ & $\mathrm{N}(>$ threshold) \\
\hline $\mathrm{N}$ & 23,548 & \\
\hline Min & 2.1 & \\
\hline Q25 & 49 & \\
\hline Median & 67 & \\
\hline Q75 & 86 & $2,340(9.9 \%)$ \\
\hline Q90 & 110 & $1,168(5.0 \%)$ \\
\hline Q95 & 131 & $591(2.5 \%)$ \\
\hline Q97.5 & 151 & $1,908(8.1 \%)$ \\
\hline Max & 1,000 & $151(0.6 \%)$ \\
\hline Median +2 MAD* & 116 & $16,328(69.3 \%)$ \\
\hline TIF & \\
\hline Upper Crust (Wedepohl, 1995) & 200 & $3,815(16.2 \%)$ \\
\hline Upper Crust (McDonough and Sun, 1995) & 97 & $2,340(9.9 \%)$ \\
\hline Upper Crust (Adriano, 1986) & 110 & $1,032(4.4 \%)$ \\
\hline Upper Crust (Kabata-Pendias, 2011) & 135 & $4,991(21.2 \%)$ \\
\hline World soil (Bowen, 1979) & 90 & $2,540(10.8 \%)$ \\
\hline World soil (Alloway, 1995) & 108 & \\
\hline World soil (Kabata-Pendias, 2011) & 129 \\
\hline Natural soil, Korea (Lee et al., 2018) & 50 & \\
\hline
\end{tabular}

*calculated from the log-transformed data

Table 2 Geochemical threshold values for vanadium of stream sediments in Geumsan and Pocheon areas 


\begin{tabular}{|c|c|c|}
\hline Statistics & Geumsan (mg/kg) & Pocheon (mg/kg) \\
\hline $\mathrm{N}$ & 33 & 20 \\
\hline Min & 56 & 37 \\
\hline Q25 & 94 & 58 \\
\hline Mean & 122 & 100 \\
\hline Median & 116 & 93 \\
\hline Q75 & 141 & 123 \\
\hline Q90 & 178 & 177 \\
\hline Q95 & 211 & 199 \\
\hline Q97.5 & 249 & 217 \\
\hline Max & 270 & 236 \\
\hline Standard deviation & 49.1 & 55.1 \\
\hline Skewness & 1.20 & 0.99 \\
\hline Median $+2 \mathrm{MAD}^{\star} \mathrm{N}(>$ threshold $)$ & $177(4)$ & $218(1)$ \\
\hline $\mathrm{TIF}^{\star} \mathrm{N}(>$ threshold $)$ & $259(1)$ & $377(0)$ \\
\hline
\end{tabular}

*calculated from the log-transformed data

Table 3 Pearson correlation coefficients between vanadium and other analyzed elements in Geumsan (lower panel) and Pocheon (upper panel) areas 


\begin{tabular}{|c|c|c|c|c|c|c|c|c|c|c|c|c|c|c|c|c|c|c|c|}
\hline & & & Poche & eon area & & & & & & & & & & & & & & & \\
\hline & & $\mathrm{V}$ & $\mathrm{CaO}$ & $\mathrm{Fe}_{2} \mathrm{O}_{3}$ & $\mathrm{~K}_{2} \mathrm{O}$ & $\mathrm{MgO}$ & $\mathrm{MnO}$ & $\mathrm{TiO}_{2}$ & $\mathrm{Ba}$ & Co & $\mathrm{Cr}$ & $\mathrm{Cu}$ & $\mathrm{Li}$ & $\mathrm{Ni}$ & $\mathrm{Pb}$ & $\mathrm{Rb}$ & $\mathrm{Sr}$ & $\mathrm{Zn}$ & $\mathrm{Zr}$ \\
\hline & $\mathrm{V}$ & & $.686^{* 8}$ & $.947^{* 8}$ & $-.811^{8 *}$ & $.720^{* 8}$ & $.720^{* *}$ & $.872^{* 8}$ & -0.179 & $.909^{* 8}$ & $.560^{*}$ & $.564^{* *}$ & -0.225 & $.613^{* 8}$ & 0.105 & $-.638^{* *}$ & 0.37 & 0.007 & -0.369 \\
\hline & $\mathrm{CaO}$ & 0.023 & & $.796^{* 8}$ & $-.735^{* *}$ & $.511^{*}$ & $.511^{*}$ & $.751^{* *}$ & -0.196 & $.653^{* *}$ & $.446^{*}$ & 0.419 & $-.561^{*}$ & 0.113 & 0.144 & -0.414 & $.765^{* *}$ & 0.273 & -0.424 \\
\hline 志 & $\mathrm{Fe}_{2} \mathrm{O}_{3}$ & $3.516^{* *} *$ & -0.036 & & $-.827^{8 *}$ & $.743^{* *}$ & $.743^{* 8}$ & $.902^{* *}$ & -0.209 & $.888^{* *}$ & $.514^{*}$ & $.668^{* 8}$ & -0.269 & $.519^{*}$ & 0.15 & $-.585^{8 *}$ & $.472^{*}$ & 0.14 & -0.343 \\
\hline 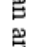 & $\mathrm{K}_{2} \mathrm{O}$ & -0.152 & -0.094 & $-.452^{* *}$ & & $-.733^{8 *}$ & $-.733^{8 *}$ & $-.697^{8 *}$ & 0.329 & $-.803^{8 *}$ & $-.602^{8 *}$ & $-.509^{*}$ & 0.394 & -0.407 & -0.15 & $.502^{*}$ & -0.256 & -0.332 & $.444^{*}$ \\
\hline & $\mathrm{MgO}$ & -0.04 & -0.009 & 0.16 & -0.334 & & $.655^{* 8}$ & $.498^{*}$ & -0.017 & $.783^{* *}$ & $.650^{* *}$ & $.739^{* 8}$ & 0.111 & $.711^{* 8}$ & 0.102 & $-.446^{8}$ & 0.092 & 0.421 & -0.32 \\
\hline & $\mathrm{MnO}$ & $.430 *$ & -0.016 & $610^{* *}$ & -0.34 & -0.041 & & $.666^{* *}$ & -0.206 & $.685^{* *}$ & 0.423 & $.714^{* *}$ & -0.226 & 0.42 & 0.248 & -0.408 & 0.385 & 0.356 & -0.285 \\
\hline & $\mathrm{TiO}_{2}$ & $.459 * *$ & -0.08 & $877^{* *}$ & $-.389^{*}$ & 0.011 & $.566 * *$ & & -0.326 & $.840^{* *}$ & 0.411 & 0.419 & -0.385 & 0.311 & 0.045 & $-.474^{8}$ & $.520^{*}$ & -0.02 & -0.316 \\
\hline & $\mathrm{Ba}$ & $.717 * *$ & -0.178 & 0.219 & 0.081 & -0.148 & 0.298 & 0.243 & & -0.212 & -0.136 & 0.089 & 0.333 & 0.172 & -0.113 & 0.066 & 0.178 & -0.202 & -0.031 \\
\hline & $\mathrm{Co}$ & $.466 * *$ & -0.083 & $.868^{* *}$ & $-.529 * *$ & 0.281 & $.638^{* * *}$ & $.667 * *$ & 0.255 & & $.542^{*}$ & $.583^{* *}$ & -0.252 & $.597^{* *}$ & -0.076 & $-.473^{\circ}$ & 0.279 & 0.109 & -0.343 \\
\hline & $\mathrm{Cr}$ & $.461^{* *}$ & -0.309 & $.757^{* * *}$ & $-.447^{*}$ & $.415^{*}$ & $.574^{*} *$ & $.566^{* *}$ & 0.233 & $.886^{* *}$ & & 0.328 & -0.173 & $.488^{*}$ & 0.087 & $-.528^{*}$ & 0.15 & $.585^{* 8}$ & $-.457^{8}$ \\
\hline & $\mathrm{Cu}$ & $.619 * *$ & 0.12 & $.382 *$ & -0.22 & 0.256 & $.469 * *$ & 0.305 & $.459 * *$ & 0.288 & 0.321 & & -0.017 & $.676^{* 8}$ & 0.331 & $-.551^{*}$ & 0.154 & 0.247 & -0.334 \\
\hline & $\mathrm{Li}$ & -0.126 & 0.087 & 0.086 & -0.335 & 0.332 & -0.17 & 0.173 & -0.152 & 0.091 & -0.032 & -0.137 & & 0.307 & 0.201 & 0.247 & -0.402 & -0.07 & 0.433 \\
\hline & $\mathrm{Ni}$ & $.414^{*}$ & -0.22 & 0.268 & -0.159 & 0.178 & $.365^{*}$ & 0.06 & 0.311 & $.345^{*}$ & $.459 * *$ & $.465 * *$ & $-.351 *$ & & 0.163 & $-.475^{*}$ & -0.048 & 0.063 & -0.155 \\
\hline & $\mathrm{Pb}$ & 0.018 & 0.08 & 0.332 & 0.063 & $-.384^{*}$ & $.671 * *$ & 0.334 & 0.03 & $.437^{*}$ & 0.279 & -0.054 & -0.315 & -0.118 & & -0.42 & 0.069 & 0.102 & -0.082 \\
\hline & $\mathrm{Rb}$ & 0.207 & $-.437^{*}$ & 0.137 & $.420 *$ & -0.247 & 0.085 & 0.164 & $.397^{*}$ & 0.07 & 0.169 & -0.066 & -0.175 & -0.002 & 0.163 & & -0.212 & 0.002 & $.525^{*}$ \\
\hline & $\mathrm{Sr}$ & -0.087 & $.657^{* *}$ & -0.327 & 0.169 & -0.331 & -0.303 & -0.253 & 0.115 & $-.433^{*}$ & $-.681^{* *}$ & -0.038 & 0.013 & -0.277 & -0.113 & -0.268 & & 0.035 & -0.236 \\
\hline & $\mathrm{Zn}$ & $.650 * *$ & -0.313 & 0.044 & 0.155 & -0.102 & $.392 *$ & 0.028 & $.694 * *$ & 0.111 & 0.209 & $.433^{*}$ & -0.119 & 0.32 & 0.043 & 0.27 & -0.196 & & -0.034 \\
\hline & $\mathrm{Zr}$ & 0.085 & -0.079 & -0.144 & 0.221 & $-.562^{* *}$ & 0.107 & -0.067 & 0.215 & $-.356^{*}$ & -0.268 & 0.206 & $-.449 * *$ & 0.119 & -0.042 & 0.115 & 0.143 & 0.13 & \\
\hline
\end{tabular}

**. Correlation is significant at the 0.01 level (2-tailed).

*. Correlation is significant at the 0.05 level (2-tailed).

Figures 


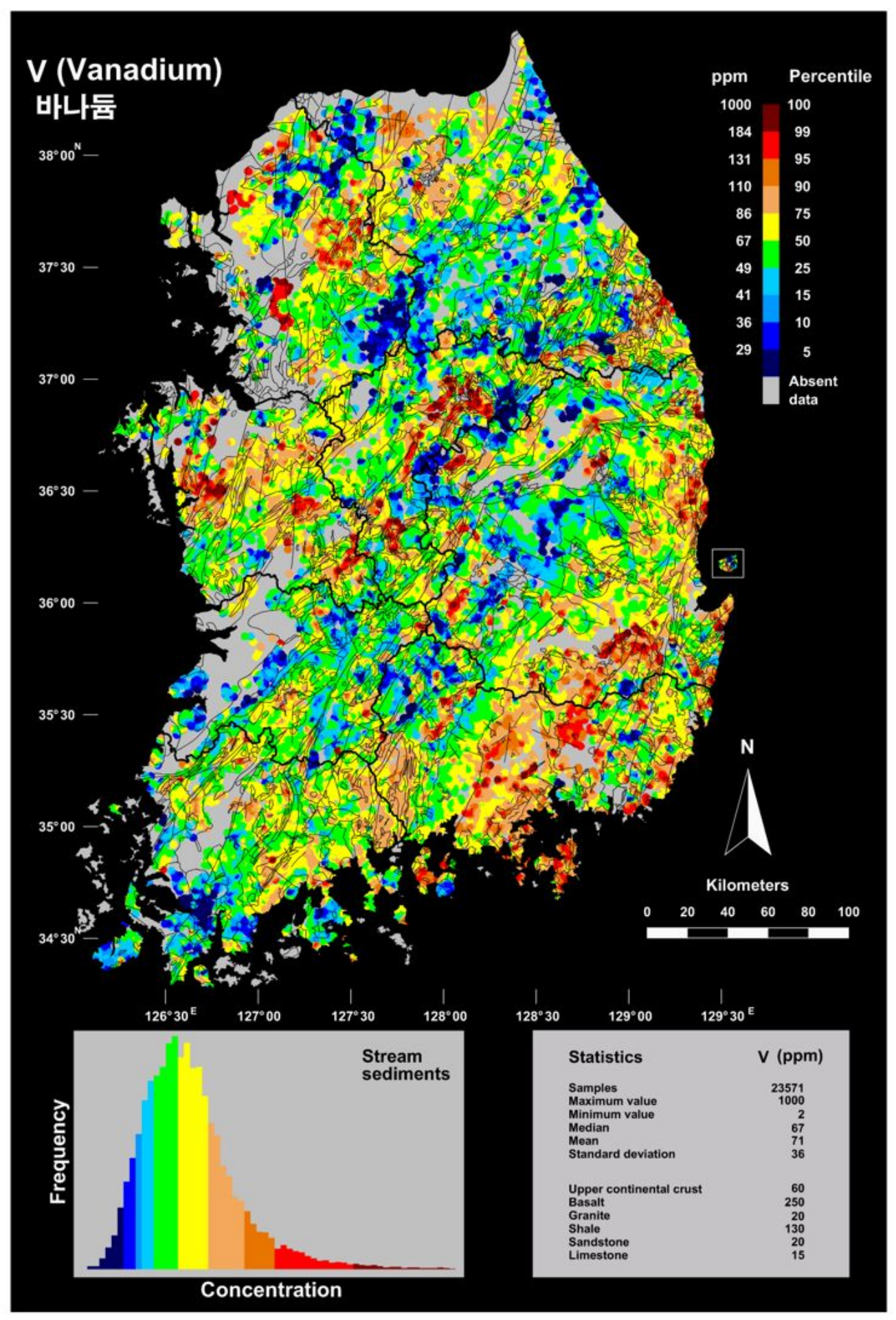

Figure 1

Geochemical map of vanadium in Korea (KIGAM 2007) 

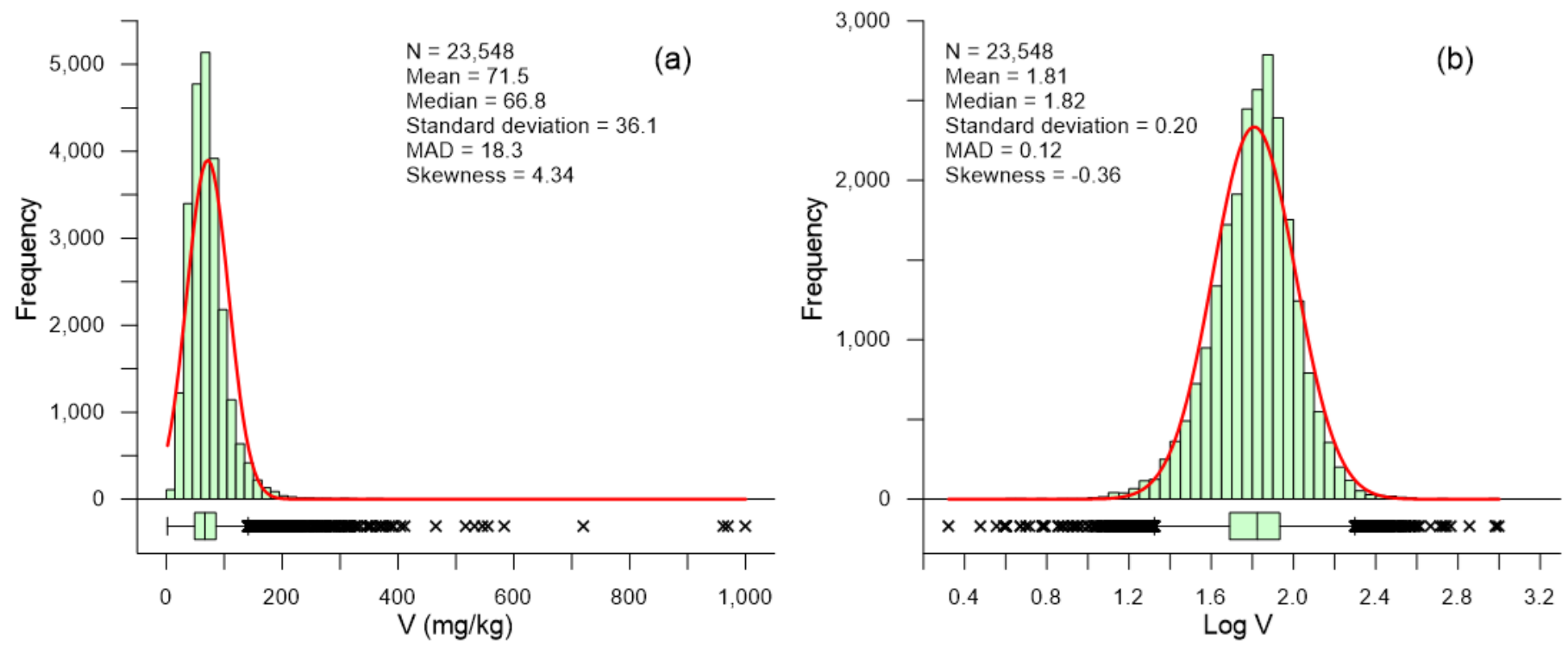

Figure 2

Histograms and boxplots of the raw (a) and log-transformed (b) vanadium data of stream sediments in Korea 

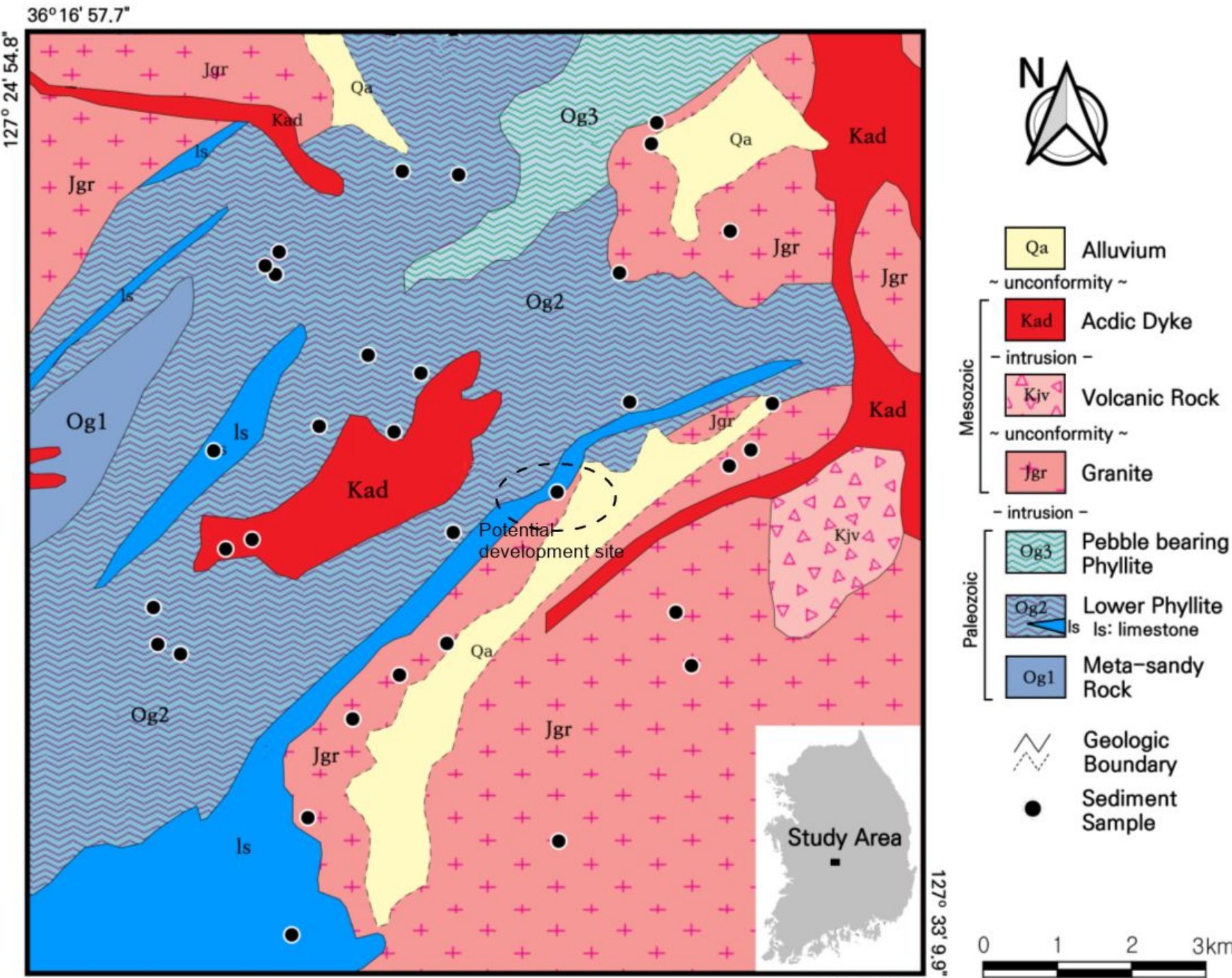

Meta-sandy

Rock

Aeologic

- Sediment

- Sample

$36^{\circ} 10^{\prime} 12.5^{\prime}$

(

\section{Figure 3}

Geologic map and sampling locations in the Geumsan area 


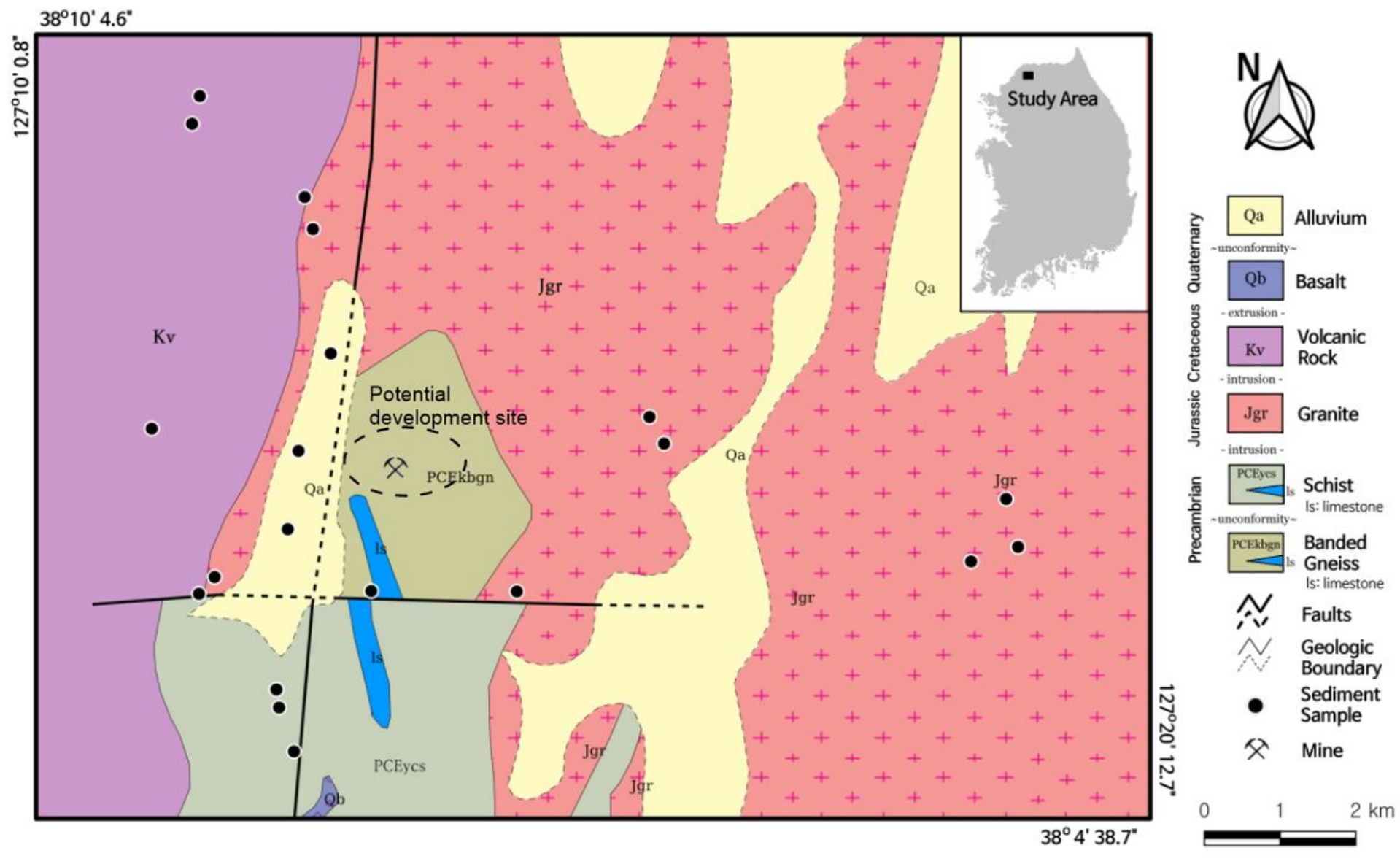

Figure 4

Geologic map and sampling locations in the Pocheon area 


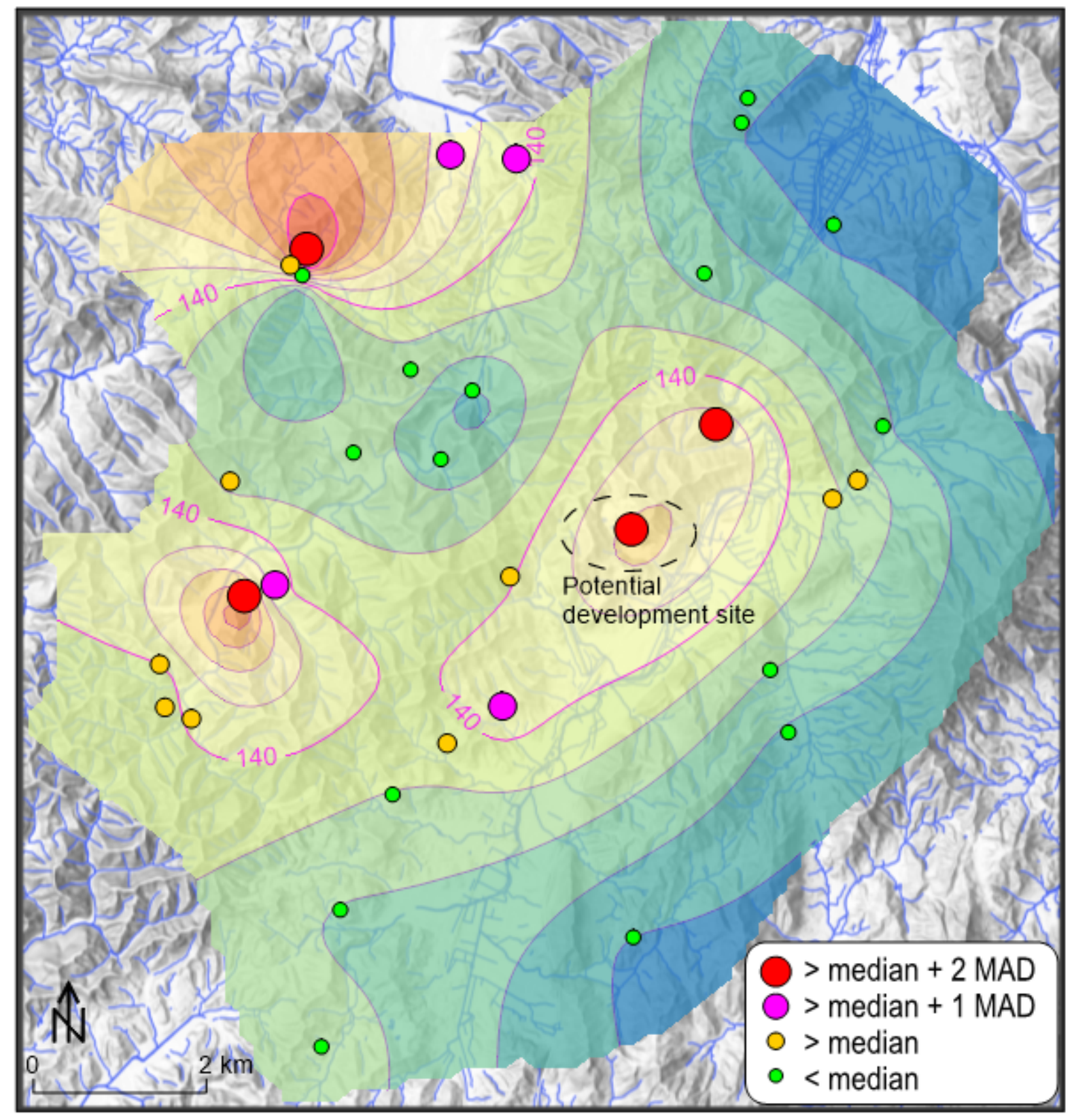

Figure 5

Spatial distribution of vanadium $(\mathrm{mg} / \mathrm{kg})$ in the Geumsan area plotted on the shaded relief map 


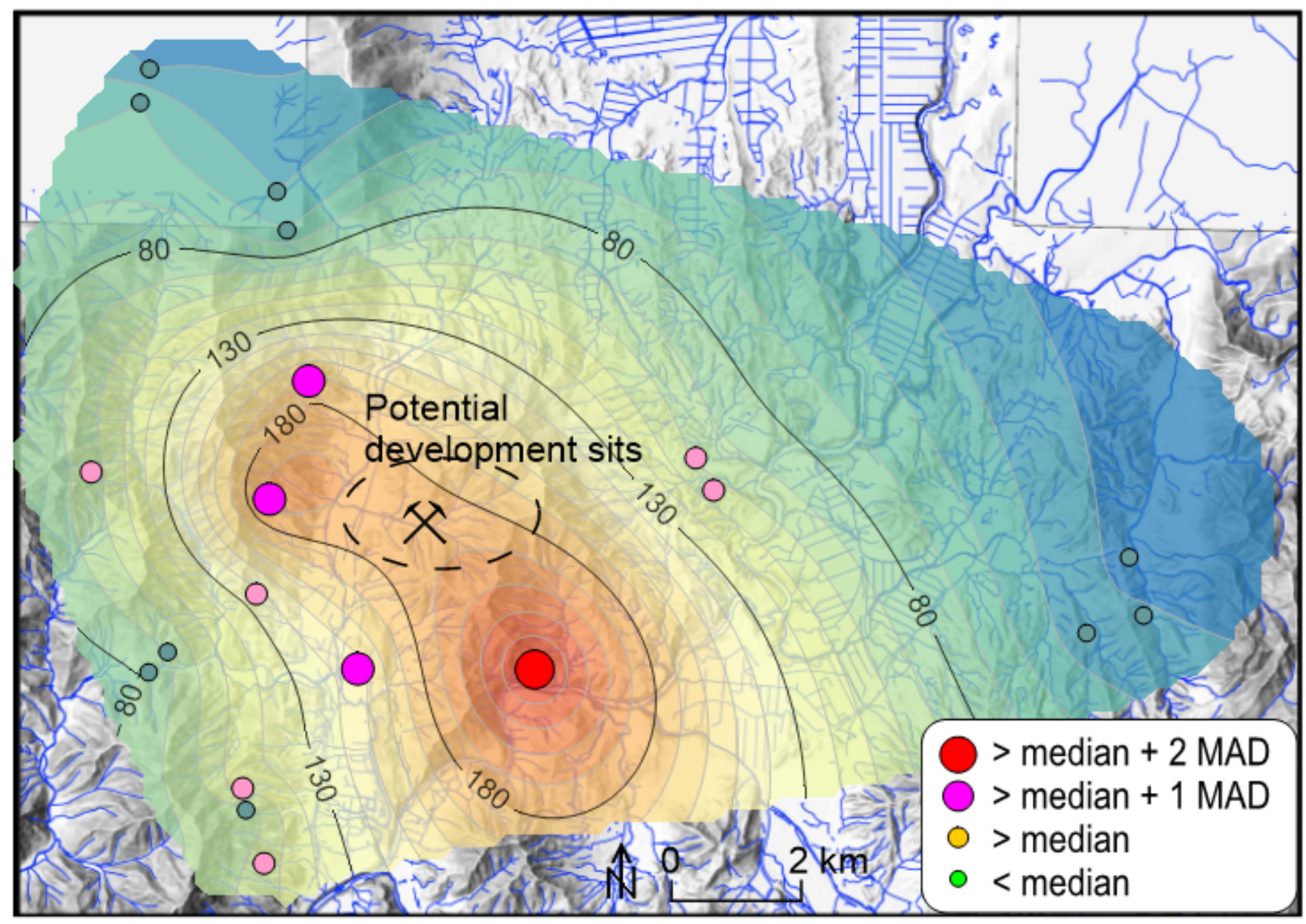

Figure 6

Spatial distribution of vanadium $(\mathrm{mg} / \mathrm{kg})$ in the Pocheon area plotted on the shaded relief map 

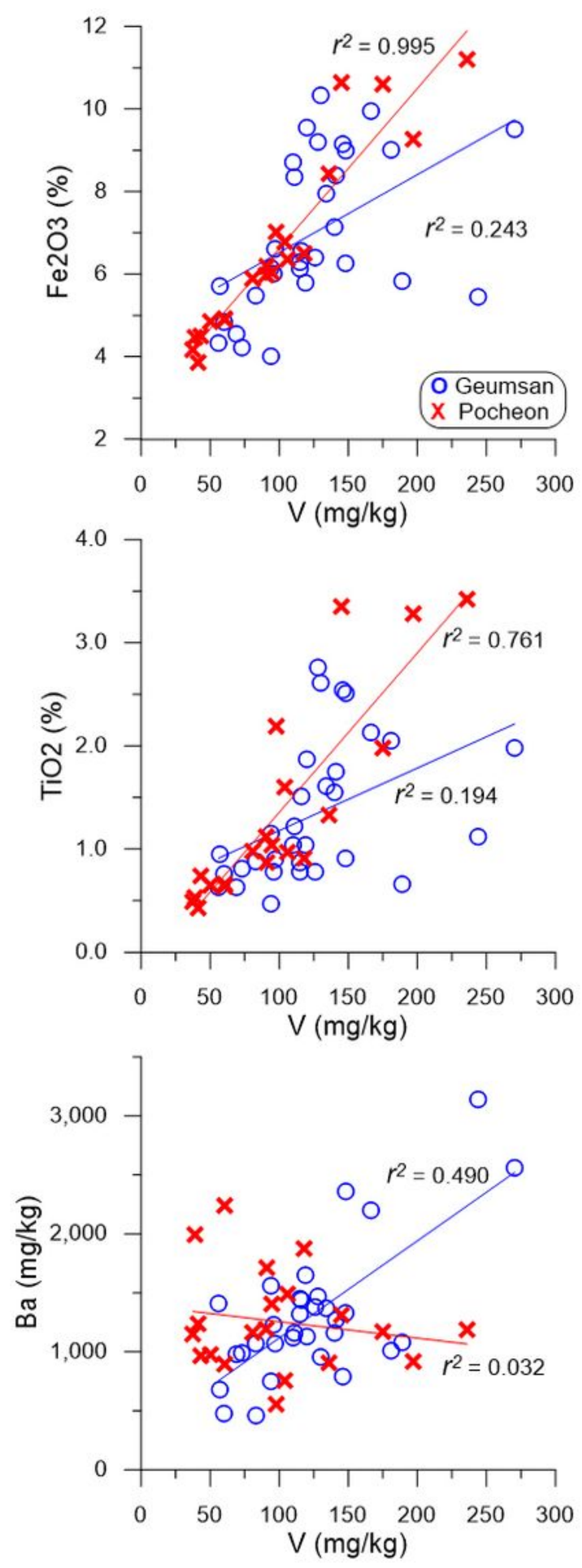

\section{Figure 7}

Relationships of vanadium with Fe2O3, TiO2 and Ba in Geumsan and Pocheon areas

\section{Supplementary Files}

This is a list of supplementary files associated with this preprint. Click to download. 
- Appendix.docx

Page 24/24 